\title{
The impact of the Brumadinho dam failure in Naô Xohâ village
}

\author{
O impacto do rompimento da barragem de Brumadinho \\ na aldeia Naô Xohã
}

Adriana Aparecida Silva ${ }^{a}$

Divina Aparecida Leonel Lunas ${ }^{b}$

Poliene Soares dos Santos Bicalhoc

Roseli Martins Tristão Maciel ${ }^{d}$

\begin{abstract}
${ }^{a}$ Docente no Programa de Pós-Graduação Stricto Sensu Interdisciplinar em Territórios e Expressões Culturais no Cerrado (Teccer) da Universidade Estadual de Goiás (UEG), Anápolis, GO, Brasil.

E-mail: veg.adriana@gmail.com
\end{abstract}

${ }^{b}$ Docente no Programa de Pós-Graduação Stricto Sensu Interdisciplinar em Territórios e Expressões Culturais no Cerrado (Teccer) da Universidade Estadual de Goiás (UEG), Anápolis, GO, Brasil.

E-mail:divalunas@gmail.com

‘Professora Titular da Universidade Estadual de Goiás (UEG), Anápolis, GO, Brasil. E-mail:poliene.soares@gmail.com

${ }^{d}$ Docente no Programa de Pós-Graduação Stricto Sensu Interdisciplinar em Territórios e Expressões Culturais no Cerrado (Teccer) da Universidade Estadual de Goiás (UEG), Anápolis, GO, Brasil.

E-mail: roselitristaomaciel@gmail.com

doi:10.18472/SustDeb.v10n3.2019.24017

Received: 10/04/2019

Accepted: 09/10/2019

ARTICLE-DOSSIER 


\begin{abstract}
It is still under strong impact from the Brumadinho dam failure that this article was written. Our main goal is to approach, in the midst of so many social groups hit by this announced tragedy, the reality of the village Naô Xohã, whose population lives on the banks of the Paraopeba River, also victimized by this environmental disaster of consequences not yet dimensioned. As it is a contemporary theme, several press releases were used to compose the narrative, as well as to build a comprehensive review of the literature on the Movement of People Affected by Dams and on socioeconomic and environmental impacts. The proposition, however, is based on an interdisciplinary approach to the theme, which is the impact of the Brumadinho dam failure in Naô Xohã village, mainly due to the pollution that spread over the Paraopeba River. To this end, a fruitful dialogue was established between history, geography, economics and environmental issues.
\end{abstract}

Keywords: Dams. Brumadinho. Paraopeba River. Indigenous Territorialities. Pataxó People.

\title{
RESUMO
}

Ainda é sob forte impacto do desastre do rompimento da barragem de Brumadinho que este artigo foi produzido. $O$ objetivo deste é adentrar, em meio a tantos grupos sociais atingidos por essa tragédia anunciada, a realidade da aldeia Naô Xohã, que vive às margens do Rio Paraopeba, também vitimada por esse desastre ambiental de consequências ainda não dimensionadas. Por se tratar de tema contemporâneo, várias publicações de imprensa foram utilizadas para compor a narrativa, além de ampla revisão da bibliografia referente ao Movimento dos Atingidos por Barragens e sobre os impactos socioeconômicos e ambientais. A proposta, todavia, embasa-se em uma abordagem interdisciplinar do tema, que é o impacto do rompimento da barragem de Brumadinho na aldeia Naô Xohã, em função, principalmente, da poluição que se espalhou pelo Rio Paraopeba. Para tanto, estabeleceu-se um diálogo profícuo entre História, Geografia, Economia e as questões ambientais.

Palavras-Chave: Barragens. Brumadinho. Rio Paraopeba. Territorialidades Indígenas. Povo Pataxó.

\section{INTRODUCTION}

Reading the sentence "the moon teaches us the right time to fish", taken from the book O Povo Pataxó e sua História (1997, p. 16), written by the indigenous teachers of Rio Doce State Park (MG), Angthichay, Arariby, Jassanã, Manguadã and Kanátyo, it is possible to measure the importance of the Paraopeba River to the Naô Xohã indigenous community, located on the banks of the mentioned river, which was also affected by the toxic mud that was spread all over the river after the Brumadinho Dam failure, on January 25, 2019.

The Pataxó Hã-hã-hãe ${ }^{1}$ community which lives on the banks of the Paraopeba River, made up of approximately 80 indigenous people, was largely sustained by the river, as it has been known since ancient times, most of the indigenous people live by hunting, gathering and fishing. The river is therefore the place from which they get part of their food, as well as a source of leisure and water supply.

Thus, the relationship of indigenous peoples with water, with the river and with the sea is millennial. It is striking how the most different indigenous peoples from Brazil and from the world have cosmogonies always permeated by the presence of waters, from which emanate beings that provide life or its continuity. Among the Yanomâmi ${ }^{2}$, it is believed that the "forest dwellers" have been born "from the vagina of Omama's wife, Thuëyoma, the woman he drew from the water" (KOPENAWA \& ALBERT, 2015, p. 82). Among the Iny-Karajá ${ }^{3}$, the relationship with the Araguaia River also highlights this intimacy with the waters, from which the livelihood, the satiety, the leisure and the mythological and explanatory stories of the origin of the people are taken. 
Karajá ethnographies point to a single narrative as the "origin myth of humanity," the one that tells how the Inỹ who inhabited the Berahatx̃i, the underwater world, lower level of the cosmos, discovered a passage to the outside world and left to live on the shores of Araguaia. (NUNES, 2016, p. 30)

With the Pataxó ${ }^{4}$ people and Pataxó Há-há-hãe1 people the story is no different, and it is no coincidence that a subgroup of the latter came to inhabit this region of the state of Minas Gerais, exactly in a place on the banks of the Paraopeba river. The origin myth of this ethnicity is also associated with water, which, when falling from the sky, in the form of rain, conceives the Indian:

One day, in the blue of the sky, a great white cloud formed, which soon turned to rain and fell to the earth. The rain was ending and the last drop of water that turned into an Indian. The Indian stepped on the ground, began to look at the forests, the birds that flew by, the water that walked with serenity, the animals that roamed freely and was fascinated by the beauty he was seeing around him (VALLE, 2001, p. 61).

The history of the Pataxó people and their relationship with the waters goes beyond this brief introduction, which sets out to present the central objective of this article. We intend to enter among so many social groups affected by this announced tragedy, the reality of the village Naô Xohã, which is located on the banks of the Paraopeba River, also victimized by this disaster of human, environmental and natural consequences not yet considered, considering the reach of huge proportions and all the tragedy.

Due to the topicality of the researched theme, the selected theoretical conception is based on the history of the present time, or contemporary history, which although "is often the target of serious criticism and censorship, due to the disadvantages of its use and legitimacy in the world contemporary society has been increasingly recognized and reinforced" (BICALHO, 2010, p. 31). The inherent obstacles to this historiographic process are acknowledged, however, it was decided to emphasize the advantages of this kind of history, since, according to François Dosse (2001), it allows "breaking causal fatalism", since subjects of study are usually unfinished; although methodologically complicated, the result of the historian's work may be "sifted through the testimonies of the events he analyzes" (DOSSE, 2001, p. 9394); "in addition to having recourse to oral sources and a diverse range of other sources: print, media, electronics and images (BICALHO, 2010, p. 31).

The research that resulted in this article is of a qualitative nature, since this methodology makes it possible to grasp the object of investigation in its entirety, in an effort to inquire into its causes, the web of relationships, mediations and contradictions that configure it, in its own dynamic interaction with a larger reality.

The qualitative research aims to analyze the social representations and the meanings that the actors involved in the investigation process attribute to the complex network of relationships that configure the object of this study. However, when necessary, the registration of quantitative data was allowed during the research, since these do not contradict the qualitative data, in fact, they complement each other (MINAYO, 2002). A bibliographic research was also performed, which includes the study of books, articles published in magazines and newspapers.

In the course of that, due to the topicality of the theme and the lack of academic papers focusing on the dam failure and the indigenous community analyzed, digital and electronic sources were used, such as news from newspapers and websites, as well as a significant review of the bibliography, considering the interdisciplinary perspective of approaching the theme, which was guided by environmental issues and the impacts of the Brumadinho dam failure on the Naô Xohã indigenous community, involving History, Geography and Economics. 


\section{IMPACTS OF DAM CONSTRUCTION AND FAILURE}

In this topic, we intend to analyze several moments of the same social problem: the peoples victimized by the breaking of the dams in Brazil during the twentieth century. There are numerous ways in which dams impact the environment and affect the way of life of traditional indigenous people, riverine and farming populations who inhabit the area where they are built and their surroundings

The negative impacts from construction are mainly related to the flooding of large areas, leading to the need of land expropriation and relocation, fragmentation of the ecosystem with loss of natural habitat of animal species; changes in channel runoff, with downstream effects on ichthyofauna and riverine population living off fishing; increased migration during the construction of the dam with economic and social consequences for the surrounding cities, when the work is completed and these immigrants are left unemployed; in addition, there is a change in the landscape and the destruction of historical and archaeological heritage, which will suffer flooding.

As for the breaking of dams, it can take the form of a major catastrophe, with the burial of large areas, leading to contamination of the soil and channel waters to the river mouth and, in some cases, to the ocean; the death of fauna and flora species; besides loss of material and immaterial memory of places and people as is the recent case of Brumadinho. Other impacts develop in a subtler way, causing the loss of several fundamental rights, such as land use, housing, water, light, mobility, among others. These cases can be exemplified by the construction of the Serra da Mesa dams in Goiás, inaugurated in 1998; and Sobradinho, in the countryside of Bahia, in the 1970s.

The social problems arising from this last example became nationally notorious thanks to the denouncement made by the artistic vein of Sá and Guarabira, through the music they composed and which bears the same name of the plant, "Sobradinho", whose refrain is the famous excerpt: "The sertão will turn into the sea and the sea will turn into the sertão", said by Antonio Conselheiro, at the end of the 19th century.

As stated above, the song Sobradinho, with its protest content, warned of the economic and social consequences with which the population of the region would have to bear because of the dam built on the São Francisco River. In fact, the construction of the dam gave rise to a huge lake that flooded the cities, which are mentioned in this song, casting out its residents from the region: "[...] goodbye Remanso, Casa Nova, Sento-Sé, goodbye Pilão Arcado comes the river swallowing you, underwater there goes your whole life [...]", records of material and immaterial losses that would come.

The construction of the dam at the Usina Hidrelétrica de Sobradinho in northern Bahia took six years and was inaugurated in 1979. As an immediate consequence of this venture, seven municipalities were flooded and more than seventy people were affected. The dam created the third largest artificial lake in the world, with a surface area of $4,214 \mathrm{~km}^{2}$ (COSTA, 1990). On the other hand, the Brumadinho dam, in Minas Gerais, was built from 1976, having several expansion moments, with prevision and deposit capacity for 12.7 million cubic meters of tailings, which initially promoted the alteration of the relief and at the base level of the Ferro-Carvão creek and the Feijão stream.

It can be affirmed that it is the actions of the State, through their administrators and their power, together with the hydroelectric or mining companies, that allow the intervention in the physical space so that the dams can be built, usually without consulting the population, as provided in the Constitution of the Federative Republic of Brazil of 1988 and Convention C169 of the International Labor Organization (ILO) of 1989. From these reflections, we will make a brief sketch about populations that were affected, most directly by these processes during the twentieth century and the first decades of the 21st century. 


\subsection{HISTORY OF DAMS AND THEIR CONSEQUENCES IN BRAZIL}

The first recorded data to which we had access about people affected by dams refer to the so-called "Brazilian Holocaust", which occurred in the 1930s. This is the Patu dam, a dam that was not completed until 1987, on the banks of the namesake river that is a tributary of the Jaguaribe hydrographic basin. In 1923 the project and the works were abandoned by order of the governor Artur Bernardes, thus becoming a concentration camp, a cemetery of fifteen thousand undead (MELLO, 2011).

The fields were created by the Federal Inspectorate of Works Against Drought (IFOCS) in 1932 as a result of a major drought in Ceará. To prevent the scourges from seeking help in the cities, making them overcrowded, they were surrounded in the crater of the dam by walls and barbed wire, where they died of malnutrition and various diseases in the "hunger pens" (Idem, p. 71).

The suffering reality through which the population went through around the unfinished Patu dam happened during the Vargas administration (1930-1945), and the concentration camps were established in 1932, before the Estado Novo, highlighting the authoritarian and fascist character that would be assumed by this politician a few years later, in 1937.

At the end of the 1940s, with the imminence of the end of World War II and the consequent return of democracies, Getúlio Vargas created, through Decree-Law no. 6.354 / 44, the National Department of Works and Sanitation (DNOS), the agency that was active in flood control ventures involving the construction of dams, polders and drainages, primarily with the aim of preventing flooding in populated areas (MELLO, 2011).

\section{TRAGEDIES WITH DAMS}

One of the first catastrophes due to dams in Brazil occurred in 1986, in the city of Itabirito-MG, with the failure of the tailings dam of Fernandinho Mine, of the Itaminas group. As a result, seven people died and much environmental damage was caused (THOMÉ; PASSINI, 2018).

From the time the Fernandinho tragedy occurred to the present day, the number of broken dams is alarming, especially in the state of Minas Gerais. What is even more tragic is the fact that during each failure, the number of victims affected, including dead, wounded, displaced and missing, increased significantly.

In June 2001, the disruption of an iron ore tailings dam at Mineradora Rio Verde destroyed the main access road and buried part of the town of São Sebastião das Águas Claras in the Macacos district of Nova Lima, metropolitan region of Belo Horizonte/MG. Five people died and seventy-nine hectares of Atlantic Forest were devastated, the information is from the State Communication Agency (2011).

Later, in 2003, the dam of the Cataguases Minas Gerais paper industry was broken, spilling a black liquor that caused the water supply to be disrupted, contaminating the Pomba and Paraíba do Sul rivers, leaving six hundred thousand people without water (MELLO, 2011).

In 2007, bauxite tailings leaked at the Mineração Rio Pomba company in Miraí, which reached a volume of two million cubic meters, displacing more than 4,000 residents and affecting four municipalities. This catastrophe also caused the interruption of water supply to the population (LACAZ; PORTO; PINHEIRO, 2017).

A failure that occurred in the spillway of the Companhia Siderúrgica Nacional dam, in 2008, flooded with mud a part of the city of Congonhas, Minas Gerais, displacing forty families (BELTRAMI; FREITAS; MACHADO, 2012). In 2014 three workers from Herculano Mineração died in Itabirito-MG, and iron mining tailings from the failured dam reached several watercourses in the region (Idem). 
One of the largest tragedies with dams occurred on November 5th, 2015, in the city of Mariana-MG, with the breach of the Samarco mega mining founder dam Fundão, founded in 1977, today under the control of Vale (50\%) and BHP Billiton Brasil (50\%). Such occupational-environmental tragedy is far from being an isolated episode, as it represents the apex of a series of events related to the growth of mega-mining in the country (PORTO, 2016). Finally, we have the tragedy of the Brumadinho Valley in 2019 , which caused the death and disappearance of approximately three hundred people.

\section{DAM FAILURE IN BRUMADINHO: HISTORICAL CONTEXTUALIZATION OF THE MUNICIPALITY}

The occupation of the territory in Brazil was marked by the entrance to the countryside, with the Bandeiras, in order to explore the natural resources of the country. The abundance of these resources motivated an increasingly and intense occupation, with the economic exploitation in the countryside. Areas such as the future state of Minas Gerais have had several expeditions since the initial period of the territorial occupation.

The Brumadinho region, in Minas Gerais, has its formation associated with the exploration of the pathfinders - paulista bandeirantes - whose chief was Fernão Dias Paes Leme (IBGE, 2019). The frontiers of the bandeirantes aimed to occupy the territory and create supply conditions for the coming communities, thus the necessity to create small villages that met the demands of supplies for the bandeiras and support for the rest of these troops.

This aspect benefited the region with the formation of a small settlement, which attracted people and small communities to the region, due to its richness in natural resources, which facilitated the establishment of small-scale productive exploration activities. The beginning of mineral exploration in Brazil in the colonial period benefited the region, which became a small iron ore mining town, an abundant resource in this territory. Another economic activity that benefited this space was the coffee culture and the implementation of railroads, an important infrastructure branch for the occupation of the mining territory. According to Silva (2018), on 02/09/1855, a contract was signed with Edward Price for the construction of the first railway section, which would originate the Central Railway of Brazil.

The railroad played a key role in enhancing the occupation of the territory and benefiting embryonic mining activities, integrating the flow system, especially products destined for the export market, such as coffee. Silva (2018) points out that the idea was the integration of the Rio das Velhas valley to the São Francisco river, with a multimodal system connecting the railroad with the river system, thus providing the union between the North and the South. This integration was achieved in 1910, with the inauguration of the trails in Pirapora, on the banks of the São Francisco River.

The Paraopeba branch was part of the region and was an attraction for workers and immigrants who came looking for opportunities, both in the agricultural activity, as well as in the mineral extraction activities. This branch was made up of 39 stations, starting in the region that would be Belo Horizonte until it reached the station of Dr. Joaquim Murtinho, in Minas Gerais (SILVA, 2018).

These factors benefited the small settlement with the establishment of small businesses, the construction of housing, thus establishing a tiny population in the region, creating the necessary conditions for the constitution of an important urban core in the interior of Minas Gerais. The region acquired municipality status under the name Brumadinho, on December 17th, 1938, by state law no. 148, when it was dismembered from the municipalities of Bonfim, Itabirito and Novo Lima (IBGE, 2019). The municipality is made up of five districts by the division presented in 2017 (IBGE, 2019), namely: Brumadinho, Aranha, Conceição do Itaguá, Piedade do Paraopeba and São José do Paraopeba.

Despite the region's natural richness and the strong presence since the foundation of the first 
settlements of mineral exploration activities, economic data on average wages and occupancy rates are below the national average. In 2016, the data indicated that the average salary was 2.4 minimum wages ( $R \$ 2,112.00)$; and the rate of employed persons in relation to the total population was $22.9 \%$. Another factor that points to a low purchasing power in the region are households with monthly incomes of up to half the minimum wage per person, which reaches the proportion of $33.5 \%$ in the municipality (IBGE, 2019).

The human development index (HDI) of 2010 indicates a value of 0.747 , above the average of the state of Minas Gerais, which is 0.731 , ninth position in Brazil among the states. These indications, presented by the municipality and the state of Minas Gerais, are classified, on a scale from 0 to 1 , as having a high index of human development.

The Brumadinho tragedy, on January 25th, 2019, has raised questions about the region's development model by provoking one of the largest life-threatening environmental disasters in Brazil. This tragedy is already considered the biggest work accident in the country, caused by the failure of the mineral tailings dam from the production of the Córrego do Feijão Mine.

This dam was built in 1976 and used the upstream elevation method (VALE, 2019). This type/method of dam construction is considered cheaper, however, this increases the risk of failure as this method uses its own waste to construct its containment structure. The failured dam went through three years without receiving waste and underwent various types of monitoring to ensure its safety, including reports from international companies, which were not sufficient to prevent the disaster. This demonstrates that the monitoring methodology and environmental reports for the mineral waste dam need a review and also an advance regarding real time mapping technologies.

Data on the area of leak impact, according to the public civil action in defense of the environment of the State of Minas Gerais, promoted by the public prosecutor of this state, highlights that:

\begin{abstract}
With the disruption of the three dams in total, about 13 million cubic meters of mining tailings containing various heavy metals and chemicals from the mining process were released into the environment. The wave of tailings resulting from the disruption of RESPONDENT's responsibility dams initially hit the company's administrative area and part of the Vila Ferteco community. According to data released by CBM/MG and CEDEC to date (11/03/2019), 200 dead and 108 missing and nearly two hundred injured were counted, among Vale employees and service providers, residents of the region and guests of a inn, as well as severe social and environmental damage throughout the Paraopeba River Basin, difficult to reverse and economic damage to residents, farmers, commerce, among other activities affected, and damage to state and municipal public purse (MINISTÉRIO PÚBLICO DE MINAS GERAIS, 2019, p.5).
\end{abstract}

In this affected area there are small farms of family farmers, rural communities and indigenous peoples living on the banks of the river. Among the main productive activities were the production of vegetables and fruits to supply the urban centers located in the region; tourist inns; and other instances of leisure. The loss of these areas can be considered a significant economic impact for the region.

\title{
4 ENVIRONMENTAL ANALYSIS OF THE IMPACTS RESULTING FROM THE DAM RUPTURE IN BRUMADINHO-MG
}

There is specific legislation on dam safety issues, which, according to Neves (2018), are: Law No. 12,334 of September 20, 2010; CNRH Resolution No. 143/2001; CNRH Resolution No. 144/2001; ANEEL Normative Resolution No. 696/2015; ANA Resolution No. 236/2016; ANM Ordinance No. 70,389 / 2017; besides state regulations. Among other elements presented by the referred laws is that the entrepreneur must elaborate a flood map of the mining dam, highlighting the water bodies involved and the environmental 
impacts resulting from a possible failure. The legislation also requires that it is the mining company's competence to elaborate and to observe, through monitoring, a Dam Safety Plan.

Vale do Rio Doce manages 133 dams in Brazil, of which 105 (80\%) are located in the state of Minas Gerais. These dams are conceptualized as reservoirs for the containment and accumulation of substances (liquid or solid) from ore beneficiation (VALE, 2019), that is, they are remnants of the ore industry, which do not receive an appropriate purpose, but are accumulated in containment areas and often overlooked.

Such waste should be properly disposed of, such as is expected to be made by Vale in the coming years, where the tailings containment structures are decommissioned or decommissioned. Vale's website presents the following news about the proposed recovery plans:

Vale has submitted to the Brazilian authorities a plan to accelerate decommissioning of all dams built by the upstream elevation method. This means that all of these will be uncharacterized as tailings dams and reintegrated into the environment. Vale currently has 10 dams built under this method and the immediate action plan is to end all of them, which are currently inactive (VALE, 2019, s/p.).

It is important to note, however, that such proposal was presented by the company after it had two of its dams ruptured (Mariana in 2015 and Brumadinho in 2019). These impacts led to unrecoverable human and environmental losses. In Brumadinho, the numbers are 249 lost human lives, not counting the 21 people still missing, according to a news posted on the G1-Globo Minas Gerais website on August 31, 2019.

In addition to the loss of human and animal lives resulting from tragedies such as this, it is important to highlight the impacts that a venture of this size has on the environment. Some impacts are related to the preparation of the area for the construction of the plant and the dams, for example: deforestation to open areas for the installation of buildings and roads; and the morphological transformation of the relief, due to the opening of trenches for mineral extraction and subsequent deposit of this material removed elsewhere, causing the isostatic compensation of the relief. Such changes modify the landscape and the environment, but their consequences are not immediately visible.

When a dam failure occurs, as in the case of the Brumadinho Córrego do Feijão Mine, the impacts are of greater proportion in terms of speed, coverage area and degradation potential. Because it is a recent tragedy, its impacts have not yet been measured on time, but it is possible to observe the change that was promoted in the landscape of the place (Figure 01).

1984

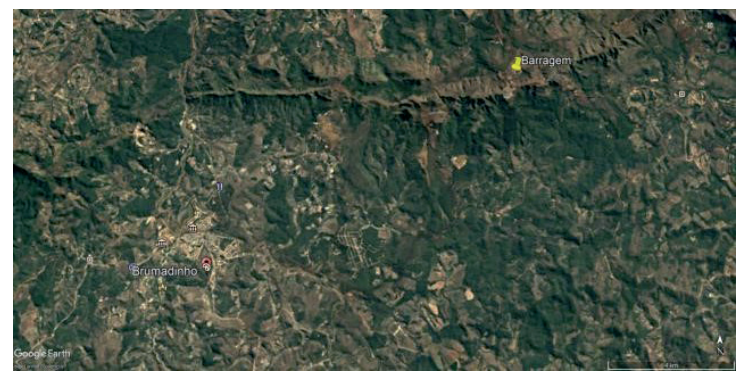

\section{9}

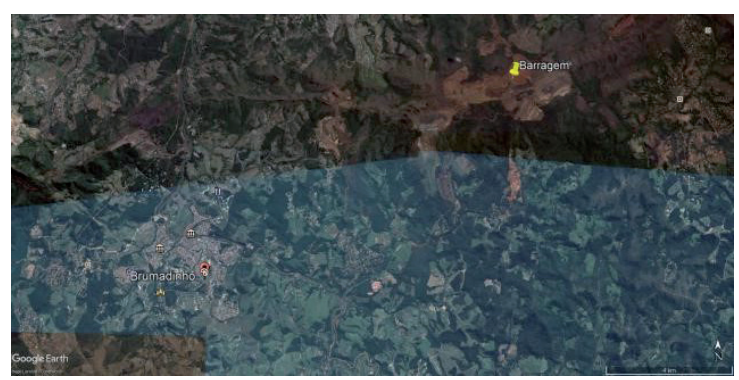

Figure 1 | Image of the disturbance area at Brumadinho dam in 1984 and 2019. Source: Google Earth, 2019.

By way of contrast, we present a reading review of a similar case study, highlighting the main direct impacts (MILANEZ; LOSEKANN, 2016; FREITAS; SILVA; MENEZES, 2016). According to these authors, the following elements of the environment are impacted and altered: 
- water resources, due to contamination by chemicals used in the extraction of ores and sediments that are transported. Such impact causes the immediate death of the ichthyofauna, and the canal itself, as the suspended sediment is deposited in the riverbed.;

- the quality of the soil, since in the area covered by the toxic mud occurs the deposit of this material rich in contaminants and particles, which when sedimented are incorporated into the first soil layers. Depending on the physical properties of this soil (if very permeable), it can reach even lower layers, causing the soil micro and macrofauna to die, making these soils unproductive and even sterile;

- $\quad$ vegetation, because wherever the mud passes, species are crushed and carried, leaving traces of sterility on the earth, which alters the resilience of native plants and interferes with the local ecosystem.

That is, such a tragedy alters the landscape, with repercussions throughout the canal watershed area, and may even exceed these limits and impact the entire downstream water system, reaching, in this case, the São Francisco River (Figure 2); and reaching the ocean, as occurred in Mariana's tragedy. This scenario leads us to reflect on the immediate impacts on the resident population of the 61 municipalities located in the Paraopeba River Basin area. These are impacts on health (physical and mental), socioeconomic and cultural, which directly and indirectly affect the socially fragile and/or vulnerable population.

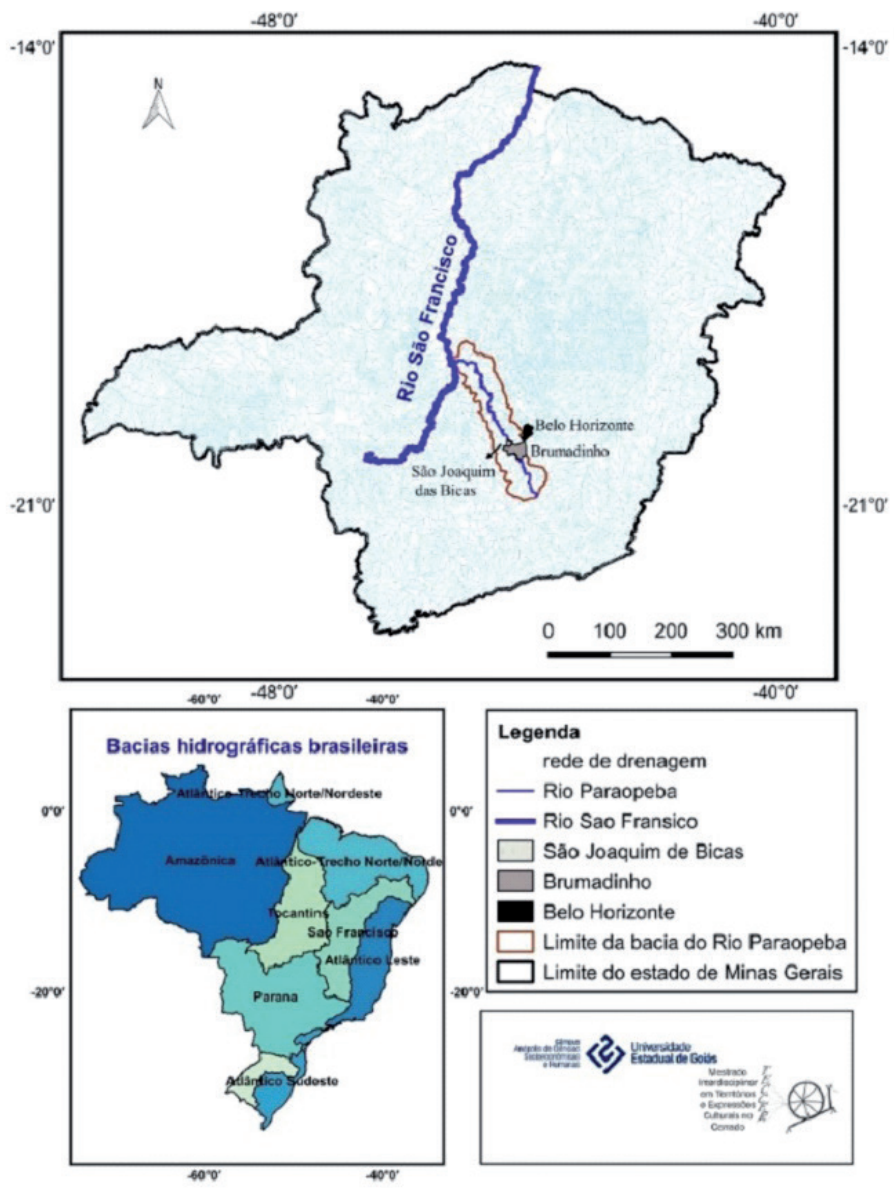

Figure 2 | Drainage map of the state of Minas Gerais, highlighting the Paraopeba and São Francisco Rivers and the Paraopeba River basin.

Source: The authors, 2019.

In this context, we highlight the presence of indigenous territorialities, such as the Pataxó Hã-hã-hãe, in the municipality of São Joaquim das Bicas, which is located in the Paraopeba river basin; in addition to the Kaxixó 7 people, in the municipality of Martinho Campos, and the Krenak8, in the municipality 
of Senhora do Porto, areas around the impacted canal. Also around are the Mangueiras and Luizes quilombos, both in the city of Belo Horizonte (Figure 3).
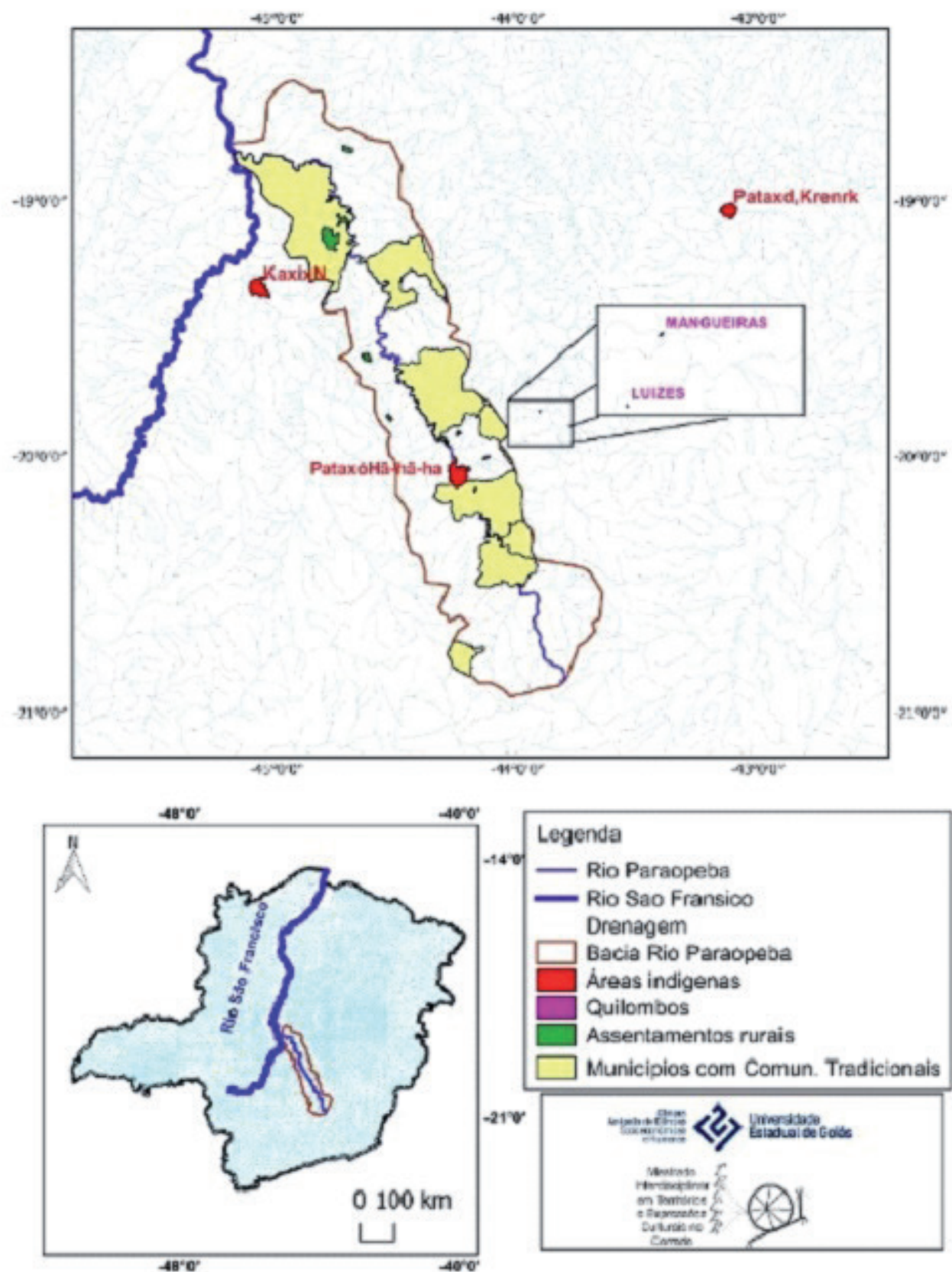

Figure 3 | Map of location of traditional populations in the Paraopeba River basin. Source: The authors, 2019.

There are also nine rural settlements in the Paraopeba River Basin area, registered in the National Institute of Colonization and Agrarian Reform (INCRA), called: Dois de Julho, 26 de Outubro, Dom Orione, Ismene Mendes, Pastorinhas, Ponte de Baixo Meleiro, Queima Fogo, Roseli Nunes and Serra Negra; besides thirteen communities termed as traditional, of which three are in the municipality of Brumadinho; another three in Belo Horizonte; two in Belo Vale; and one in each of the municipalities of Pompu, Paraopeba, Contagem, Moeda and Resende Costa. 


\section{NAÔ XOHÃ: AN INDIGENOUS TERRITORIALITY ON THE BANKS OF THE PARAOPEBA RIVER}

The Naô Xohã indigenous village settled on the banks of the Paraopeba River about two years ago, in 2017, most likely as a result of constant migrations from the Pataxó and Pataxó Hã-hã-hãe people. According to the website of Instituto Socioambiental, the Pataxó presence in the state of Minas Gerais, coming from the state of Bahia, can be explained from three basic episodes: the massacre know in Brazil as O Fogo de 519; the creation of the Monte Pascoal National Park; and the recognition of the Pataxó people by the National Indian Foundation (FUNAI), in 1971, because the FUNAI agency, at the time existing in Minas Gerais, could better assist them10.

Regarding the Naô Xohã village specifically, no academic study was found, considering its recent history. The relationship of this indigenous community with the occupation of this space, since 2017, on the banks of the Paraopeba River, is explained throughout the contact experiences lived by the Pataxó people for centuries. It is certainly not a traditional territory from a historical perspective of immemorial presence with and in place. On the contrary, it refers to a type of appropriation of space from contact experiences, certainly destabilizing the group's original territorial experience, leading it to dispersion, since "contact is effectively an experience that adds elements to territoriality, leading to the creation of new strategies" (GALLOIS, 2004, p. 40).

In this perspective, we work with what is currently recognized by indigenous territorialities, that is, "it can be said that contact puts an indigenous group before spatial logics that are different from their own and that are now also expressed in territorial terms".

As we have seen, contact is a context of confrontation between spatial logics. For this reason, the various forms of regulating the indigenous territorial issue implemented by the National States cannot be seen only from the angle of the recognition of the right to "land", but as an attempt to resolve this confrontation (GALLOIS, 2004, p. 41).

In this sense, Naô Xohã village can be characterized as a recent indigenous territoriality, since the group identifies with the place and expects to settle in it and experience a culture similar to that traditionally experienced by them or their ancestors. In an attempt to situate it historically, we had to resort to information from some websites and bloggers, as these provide some information, although it may still be misleading and unreliable about the community. However, they are the only sources of research found. Due to the failure of the Brumadinho Dam, even several sites from different origins released information about the community, because it was released by some of the victims of the tragedy.

On the Brasil de Fato11 website, an information channel of the state of Minas Gerais, in a publication of August 30th, 2018, signed by Wallace Oliveira, there is exclusive information about Naô Xohã village. The group was formed, through a consummate occupation in 2017, by a cluster of about 30 people, including children, adults and the elderly, in São Joaquim de Bicas, metropolitan region in Belo Horizonte. Also according to the news published on the site, it would be a cluster of people belonging to different ethnicities, speakers of dialects originating from the native language Patxohã, source from which originates the name of the village: "warrior spirit".

The aim of the group would be to work on the land in order to recover it, considering its state of advanced degradation, and to achieve better living conditions, which in the city (Belo Horizonte), where they used to live, they could not enjoy. Meanwhile, Wallace Oliveira also presents the speech of the indigenous teacher Avelin Buniacá Kambiwá, from the ethnic group Kambiwá, from Pernambuco, also belonging to the community, according to which "the land is very degraded, it is not possible to live on it. The river is polluted and has to be saved. We have to be there to save the Paraopebas River, the rest of the forest that still has and stop this mining" (OLIVEIRA. In: Brasil de Fato). 
From this statement, it seems that the Paraopeba River, even before the Brumadinho disaster, was already suffering from water pollution as a result from deforestation and mining, but that, under indigenous logic, could be recovered, as the fishing and water use were still possible, and these are the things that provided the immediate survival conditions of the group.

After the dam broke, the mud traveled $7 \mathrm{~km}$ to reach the Paraopeba River, according to a report published in G1-Minas Gerais, on January 27, 201912, impacting the territory of Naô Xohã village. The 93-year-old indigenous named Gervasio Ânkohay and one of the residents of the affected community, according to Diego Toledo, said, still under heavy impact from the tragedy:

"It was a beautiful river, they ended the life there." Surrounded by Brazilian and foreign journalists and TV crews, a group of locals went to the riverbank, playing indigenous instruments and singing a song that called for respect for the rules of nature. Since Friday, the Indians say they have already removed more than three large bags of dead fish from the Paraopeba River (TOLEDO, 2019, UOL-Notícias).

Returning to the introduction of this article, the relationship of deep interdependence between man and nature, more specifically between the indigenous and the waters, is confirmed in this statement by Deputy Native Chief Célia Peixoto, from Naô Xohã village, published in the Estado de Minas newspaper: "The pataxó people came from a drop of water that fell on the earth, our relationship with the water is very strong ... The dead river causes us regret." Still from the perspective of what we can learn from indigenous people, the speech of indigenous leader Hayô summarizes the essence of what we wanted to demonstrate here: "We must respect nature and say no to mining companies" (Greenme, online); as well as another resident of the community, the indigenous Werymerry, complements: "The earth is vomiting. She is sick. Everything that destroys nature destroys itself."

\section{FINAL CONSIDERATIONS}

Until the Brumadinho dam failure, Naô Xohã village remained almost unknown. It became evident on regional, national and international levels only after this tragedy - that could have been prevented if there were greater oversight and punishment for human and environmental crimes in Brazil. What can be learned from indigenous people in this and similar situations is perhaps the greatest lesson that can be learned in the face of a reality in which economic factors still subdues life: it is necessary to take care and respect nature, understanding ourselves as part of it. This is what the indigenous people teach us all the time.

Given the fact that the tragedy is still very recent, its indirect impacts are not yet fully known, so the scenario of projected impacts for the region, both economically and environmentally, requires further studies; mainly with interdisciplinary methodologies, which include various aspects of knowledge: economic, social, cultural and environmental. Nature's very characteristic of resilience has been affected by the effects of man's disorderly occupation and recurrent tragedies, such as Brumadinho's, which diminish the ability of the environment to process and resolve the negative externalities of these events, whether by their magnitude, be it for the brevity between the event and the time of nature.

However, it has been shown that the environmental disaster and the impact on the lives of those affected, especially in this article, the indigenous community approached, is of colossal proportions. The Paraobeba River was a source of life for the Nao Xohã, as it was for the many other people affected. Nature's time tends to reestablish life, but these people, indigenous and non-indigenous, will still be alive to watch it? Will the people directly involved in this tragedy be effectively held responsible and will fulfill their duties to provide the conditions for the environmental recovery of the affected nature, as well as those who have been and will still be victims of this tragedy?

In short, we end up with more questions than answers, as this story still needs time to be analyzed more 
accurately. However, actions to undo human and environmental impacts as quickly as possible demand urgency. As presented, such tragedies could be avoided if laws were seriously observed and the major concern encompassed human life and the preservation of natural and environmental resources. Yet, what we have is the prioritization of capital gain and the reduction in spending on impact prevention, which destroys nature and its people, especially those that make up the most vulnerable population.

\section{NOTES}

1. Some press sources and websites have referred to the affected indigenous community as belonging to the Pataxó Hã-hã-hãe people. Looking at the data from the Instituto Socioambiental (ISA) website, referring to the Pataxó and Pataxó Hã-hã-hãe peoples, it was found that they are, in fact, the Pataxó in Minas Gerais, besides Bahia; while the Pataxó Hã-hã-hãe are located exclusively in Bahia. However, according to FUNAI data, published on the Estado de Minas website, "more than 80 Pataxó Hã-hã-hãe indigenous people live in Naô Xohã village, on the banks of the Paraopeba River. Source of support for the community, the river was hit by mud and mineral waste, threatening the supply not only of the Indians, but also of the residents of several cities whose drinking water comes from Paraopeba". Thus, the inhabitants of the village will be considered to be Pataxó Hã-hã-hãe, in view of the possibility of recent migrations of representatives of this people to the state of Minas Gerais. Available: https://www.em.com.br/app/noticia/gerais/2019/01/28/interna_gerais,1025323/funai-dara-apoio-aindios-que-vivem-perto-de-barragem-rompida.shtml. Acess: 03/25/2019.

2. Yanomami: Inhabitant to the states of Amazonas, Roraima and Venezuela, according to ISA data, today there are 24,306 speakers of the Yanomami Linguistic Family. Disponível: https://pib.socioambiental.org/pt/ Povo:Yanomami. Acesso: 03/23/2019.

3. Iny-Karajá: They are spread among the states of Goiás, Mato Grosso, Pará and Tocantins, and according to ISA data, today there are 3768 people speaking from the Karajá Linguistic Family. Available: https://pib.socioambiental. org/pt/Povo:Karaj\%C3\%A1. Acess: 03/23/2019.

4. Pataxó: They inhabit the states of Bahia and Minas Gerais, and today, according to ISA data, there are 12,326 speakers of the Pataxó Linguistic Family. "The Pataxó live in several villages in the extreme south of the state of Bahia and northern Minas Gerais. There is evidence that the village of Barra Velha has existed for nearly two and a half centuries since 1797 (see occupation history). In contact with non-Indians since the 16th century and often forced to hide their customs, the Pataxó today strive to live their Pataxohã language and "ancient" rituals such as Awê. Available: https://pib.socioambiental.org/pt/Povo:Patax\%C3\%B3. Acess: 03/23/2019.

5. Pataxó Hã-hã-hãe: According to ISA data, they inhabit the state of Bahia, and today there are 2,866 people who speak the indigenous language of the Pataxó Hah-huh language family. "In their entirety, the Indians known under the encompassing ethnonym Pataxó Hãhãhãe today include the Baenã, Pataxó Hãhãhãe, Kamakã, Tupinambá, Kariri-Sapuyá and Gueren ethnic groups. Inhabitants of southern Bahia, the history of these groups' contact with non-indigenous people was characterized by expropriations, forced displacement, disease transmission and murder. The land reserved for them by the state in 1926 was invaded and largely converted to private farms. Only from the 1980s began a slow and tortuous process of retaking these lands, the outcome of which seems still far away, with the Reserve remaining sub judice." Available: https://pib.socioambiental.org/pt/ Povo:Patax\%C3\%B3_H\%C3\%A3-H\%C3\%A3-H\%C3\%A3e. Access: 03/23/2019.

6. The minimum wage of 2016 was $R \$ 880.00$ and the average Brazilian salary was $R \$ 2,124.00$. (IBGE, 2019).

7. Kaaxixó: inhabitants of the territory of Minhas Gerais and today there are about 301 people. Available: https:// pib.socioambiental.org/pt/Povo:Kaxix\%C3\%B3. Access 03/25/2019.

8. Krenak: inhabitants of the states of Minas Gerais, Mato Grosso and São Paulo, and today are about 434 people who speak the Krenák Linguistic Family. Available: https://pib.socioambiental.org/pt/Povo:Krenak. Access: 03/25/2019. 
9. Episode related to the process of recognition and demarcation of the Pataxó indigenous territory, around Monte Pascal, in Barra Velha, Bahia. After the terrain was measured, controversies arose among the indigenous people, and the Pataxó would have manifested their opposition, as an injured group and rights holders over the territory. According to Maria Regina Lins Brandão Veas, "Around this fact there is much controversy, as some said that the measurement was at the behest of the Bahia government while others said it was at the behest of Getúlio Vargas himself. But the important thing is that, when narrating this event, some facts are clear, for example, that the measurement started in Caraiva reaching Barra Velha and that the demarcation was performed with the help of the indigenous people. They realized that, from time to time, the measurement exceeded the correct size of the stipulated area, which caused concern. This unrest lasted for years, until the Indians decided to call for recognition of the land. Thus, the Barra Velha village chief went on a trip to Rio de Janeiro, went to SPI and, unable to obtain information, returned to Bahia. Sometime later a group of men came to Barra Velha village saying that they would solve the land problem. However, they tell the Pataxós themselves that it was an ambush, in which the cable line was cut and the Indians held hostage in their own village, until they realized the cheating. Soon an invasion of policemen from both sides of the village erupted and they began to fire at the dwellings. They invaded the village, destroying the houses with fire. It was no longer known who fought against whom, however, the blame eventually fell on the Indians, who were eventually arrested. Some Indians fled and hid in the woods for days, others went out and scattered on the farms. It was not long before, and a statement from Salvador caused the true culprits of all the confusion to be arrested. Those pretending to be benefactors had dealt the blow. Maria, the oldest Indian in Muã Mimatxi village, tells us that, on the occasion of the "Fogo de 51", many people fled, since it was no longer possible to live in Barra Velha. At the time, D. Maria and other Indians rushed to a farm where her father lived. Her husband, who had been in the ambush, would later tell her about it." (VEAS, 2017, p. 33-34).

10. Pataxó. Socio-environmental Institute. Available: https://pib.socioambiental.org/pt/ Povo:Patax\%C3\%B3\#Popula.C3.A7.C3.A3o. Access: 03/18/2019.

11. OLIVEIRA, Wallace. Indígenas retomam terra em São Joaquim de Bicas (MG). Aldeia Naô Xohã surgiu para recuperar terra degradada e proporcionar uma vida melhor para famílias. Brasil de Fato. Belo Horizonte (MG), 30 de Agosto de 2018 às 08:00. Available: https://www.brasildefato.com.br/2018/08/30/indigenas-retomam-terraem-sao-joaquim-de-bicas-mg/. Access: 03/18/2019.

12. Tragédia em Brumadinho: o caminho da lama. G1-Minas Gerais. Available: https://g1.globo.com/mg/ minas-gerais/noticia/2019/01/27/tragedia-em-brumadinho-o-caminho-da-lama.ghtml. 27/01/2019. Access: 09/25/2019.

\section{REFERENCES}

ALVES, V. Disponível em: <valdecyalves.blogspot.com/2017/barragem-do-patu-barragem-da-morte.html>.

ANGTHICHAY; ARARIBY; JASSANÃ; MANGUADÃ; KANÁTYO. O Povo Pataxó e sua História. Programa de Implantação das Escolas Indígenas em Minas Gerais. MEC, SEE,Funai, IEF. Minas Gerais: Parque Estadual do Rio Doce, 1997.

AUR, D. Lama tóxica nas terras dos índios Pataxós: uma tragédia da qual ninguém fala. GRENME. 07/02/2019. Disponível em: <https://www.greenme.com.br/informar-se/povos-da-floresta/7570-lama-toxica-terras-indiospataxos-brumadinho>. Acesso em: 25 mar. 2019.

BELTRAMI A. C.; FREITAS, C. M.; MACHADO, J. H. M. Acidentes com produtos perigosos no Brasil, no período 20062009: análise dos dados dos sistemas de informações como subsídio às ações de vigilância em saúde ambiental. Epidemiol. Serv. Saude. Brasília, v. 3, n. 21, p. 439-48, 2012.

BICALHO, P. S. dos S. Protagonismo Indígena no Brasil: movimento, cidadania e direitos (1970-2009). (Tese de Doutorado). Programa de Pós-Graduação em História Social, Universidade de Brasília, Brasília, 2010. 468 f. 
COSTA, A. L. B. M. Barragem de Sobradinho: o desencontro cultural entre camponeses e técnicos do Estado. In: Hidrelétricas, ecologia e progresso: contribuições para um debate. Rio de Janeiro: Cedi, 1990.

DOSSE, F. A História à prova do tempo: da história em migalhas ao resgate do sentido. São Paulo: Ed. Unesp, 2001.

ESTADO DE MINAS. Funai dará apoio a índios que vivem perto da barragem rompida. Disponível em: <https:// www.em.com.br/app/noticia/gerais/2019/01/28/interna_gerais,1025323/funai-dara-apoio-a-indios-que-vivemperto-de-barragem-rompida.shtml>. Acesso em: 25 mar. 2019.

FREITAS, C. M. de; SILVA, M. A. da; MENEZES, F. C. de. O desastre na barragem de mineração Samarco - fratura exposta dos limites do Brasil na redução de risco de desastres. Revista Ciência e Cultura. v. 68, n.3, São Paulo, jul/set. 2016.

GALLOIS, D. T. Terras ocupadas? Territórios? Territorialidades? In: RICARDO, F. (Org.) Terras Indígenas e Unidades de Conservação da Natureza. São Paulo: ISA - Instituto Socioambiental, 2004. p. 37-41 (PDF).

INSTITUTO BRASILEIRO DE GEOGRAFIA E ESTATÍSTICA. 2019. Dados econômicos. Disponível em: < https://cidades. ibge.gov.br/brasil/mg/brumadinho/panorama>. Acesso em: 10 mar. 2019.

JORNAL ESTADO DE MINAS. Disponível em: <https://www.em.com.br/app/noticia/gerais/2019/03/21/interna_ gerais,1039797/numero-de-mortos-em-brumadinho-sobe-para-210-seguem-desaparecidos-99.shtml>. Acesso em: 21 mar. 2019.

KOPENAWA, D.; BRUCE, A. A queda do Céu: palavras de um xamã yanomami. São Paulo: Companhia das Letras, 2015.

LACAZ, F. A. C.; PORTO, M. F. de S.; PINHEIRO, T. M. M. Tragédias brasileiras contemporâneas: o caso do rompimento da barragem de rejeitos de Fundão/Samarco. Revista Brasileira de Saúde Ocupacional. São Paulo, v. 42, 2017.

MELLO, F. M. (Coord). A história das Barragens no Brasil, Séculos XIX, XX e XXI: cinqüenta anos do Comitê Brasileiro de Barragens. Rio de Janeiro: CBDB, 2011. Disponível em: <http://www.cbdb.org.br/documentos/A_ Historia_das_Barragens_no_Brasil.pdf>.

MILANEZ, B.; LOSEKANN, C. (Org.) Desastre no Vale do Rio Doce: antecedentes, impactos e ações sobre a destruição. Rio de Janeiro: Folio Digital: Letra e imagem, 2016.

MINAYO, M. C. de S. (Org). Pesquisa social: teoria, método e criatividade. Petrópolis, RJ: Vozes, 2002.

MINISTÉRIO PÚBLICO DE MINAS GERAIS. Ação civil pública em defesa do meio ambiente. Brumadinho, 13 mar. 2019, 120p.

NEVES, L. P. Segurança de barragens: legislação federal brasileira em segurança de barragens comentada. Brasília, 2018. Disponível em: <http://www.anm.gov.br/assuntos/barragens/e-book-livre-legislacao-federal-brasileiraem-seguranca-de-barragens-autor-luiz-paniago-neves>. Acesso em: 21 mar. 2019.

NUNES, E. S. Transformações Karajá: os "antigos" e o "pessoal de hoje" no mundo dos brancos. (Tese de Doutorado) - Universidade de Brasília, Programa de Pós-Graduação em Antropologia Social, Brasília: 2016.

OLIVEIRA, W. Indígenas retomam terra em São Joaquim de Bicas (MG). Aldeia Naô Xohã surgiu para recuperar terra degradada e proporcionar uma vida melhor para famílias. Brasil de Fato. Belo Horizonte (MG), 30 de Agosto de 2018. Disponível em: <https://www.brasildefato.com.br/2018/08/30/indigenas-retomam-terra-em-saojoaquim-de-bicas-mg/>. Acesso em: 18 mar. 2019.

PATAXÓ.InstitutoSocioambiental.Disponívelem:<https://pib.socioambiental.org/pt/Povo:Patax\%C3\%B3\#Popula. C3.A7.C3.A3o>. Acesso em: 18 mar. 2019. 
PORTO, M. F. S. A tragédia da mineração e do desenvolvimento no Brasil: desafios para a saúde coletiva. Cadernos de Saúde Pública. Rio de Janeiro, n. 32, v. 2, 2016. Disponível em: <http:// www.scielo.br/pdf/csp/v32n2/0102311X-csp-32-20102-311X00211015.pdf>.

PREFEITURA MUNICIPAL DE BRUMADINHO. Prefeito negocia e Vale vai continuar pagando royalties por dois anos. Disponível em: < https://portal.brumadinho.mg.gov.br/prefeito-negocia-e-vale-vai-continuar-pagandoroyalties-por-dois-anos/>. Acesso em: 11 mar. 2019.

SILVA, F. S. Patrimônio Ferroviário em Minas Gerais: bens imóveis. Brasília: Iphan, Ministério da Cultura. 2018. Disponível em: <http://portal.iphan.gov.br/uploads/ckfinder/arquivos/Patrimonio_Ferroviario_MG.pdf>. Acesso em: 10 mar. 2019.

THOMÉ, R.; PASSINI, M. L. Barragens de rejeitos de mineração: características do método de alteamento para montante que fundamentaram a suspensão da utilização em Minas Gerais. Ciências Sociais Aplicadas em Revista. Paraná, v. 18, n. 34, 2018.

TOLEDO, D. Homem branco fez terra vomitar, diz líder de aldeia afetada em Brumadinho. UOL Notícias. 31/01/2019. Disponível em: <https://noticias.uol.com.br/cotidiano/ultimas-noticias/2019/01/31/homembranco-fez-terra-vomitar-diz-lider-de-aldeia-afetada-em-brumadinho.htm?cmpid=copiaecola>. Acesso em: 18 mar. 2019.

VALLE, C. Txopailtohã: mito fundador pataxó. Acta Scientiarum. Maringá, v. 23, n. 1, p. 61-68, 2001.

VALE. Entenda as barragens da Vale. Disponível em: <http://www.vale.com/brasil/pt/aboutvale/servicos-paracomunidade/minas-gerais/atualizacoes_brumadinho/paginas/entenda-as-barragens-da-vale.aspx >. Acesso em: 17 mar. 2019.

VALE. Disponível em: <http://www.vale.com/brasil/PT/aboutvale/servicos-para-comunidade/minas-gerais/ atualizacoes_brumadinho/Paginas/Entenda-as-barragens-da-Vale.aspx>. Acesso em: 21 mar. 2019.

VEAS, M. R. L. B. Histórias indígenas e suas potencialidades para a educação intercultural: um estudo na aldeia MuãMimatxi. (Dissertação de Mestrado). Programa de Pós-graduação em Educação e Formação Humana. Universidade do Estado de Minas Gerais. Belo Horizonte, 2017. 